The Origins of the Second World War 


\section{The Origins of}

the Second World War

Historical Interpretations

edited by

E. M. ROBERTSON 
Selection and editorial matter (C) E. M. Robertson 1971

All rights reserved. No part of this publication may be reproduced or transmitted, in any form or by any means, without permission.

$$
\begin{aligned}
& \text { First published 197I by } \\
& \text { MACMILLAN AND CO LTD } \\
& \text { London and Basingstoke }
\end{aligned}
$$
Associated companies in New York Toronto Dublin Melboume Johannesburg and Madras

Library of Congress catalog card no. 72-129636

ISBN 978-0-333-11461-2

ISBN 978-1-349-15416-6 (eBook) DOI 10.1007/978-1-349-15416-6

The Papermac edition of this book is sold subject to the condition that it shall not, by way of trade or otherwise, be lent, resold, hired out, or otherwise circulated without the publisher's prior consent, in any form of binding or cover other than that in which it is published and without a similar condition including this condition being imposed on the subsequent purchaser. 


\section{Contents}

Acknowledgements vii

Introducton: World War II: The Historians and their Materials

E. M. Robertson

1 The Historiography of World War II

T. Desmond Williams

2 The Conquest of the Past: Some Recent German Books on the Third Reich James Joll

3 A. J. P. Taylor, Hitler and the War

H. R. Trevor-Roper

4 (a) How to Quote: Exercises for Beginners 100 A. J.P. Taylor

(b) A Reply

$H . R$. Trevor-Roper

102

5 Some Origins of the Second World War T. W. Mason

6 War Origins Again A.J.P. Taylor

7 Critics of the Taylor View of History

C. Robert Cole

8 Hitler and the Origins of the Second World War: Second Thoughts on the Status of Some of the Documents H. W. Koch

9 Hitler and the Origins of the Second World War Alan Bullock 
10 Document: The Secret Laval-Mussolini Agreement of 1935 on Ethiopia

D. C. Watt

11 Japanese Imperialism and Aggression: Reconsiderations, II

Akira Iriye

12 Japan's Foreign Policies between World Wars: Sources and Interpretations 262 Akira Iriye

13 Pearl Harbor and the Revisionists Robert H. Ferrell

Notes on Contributors

Select Bibliography

Index 


\section{Acknowledgements}

Acknowledgements are due to the editors of the following publications for permission to republish the articles included in this volume: The Historian; Historical Studies (Proceedings of the Irish Historical Conferences); International Affairs; Encounter; Past and Present; The Wiener Library Bulletin; The Historical Journal; Proceedings of the British Academy; The Middle East Journal; The Journal of Asian Studies.

I am greatly indebted to $\mathrm{Dr} \mathrm{H}$. W. Koch, who is editing a similar volume to this one on the causes of the Second World War, and to Messrs Owen Dudley Edwards and Victor Kiernan for most valuable suggestions; to Mr Colin Davies, Miss A. Jill R. McIntyre and $\mathrm{Dr} H$. Graml for the patient help in the editorial work. I owe a great deal to the stimulus provided by my students, who read as their special subject The Rome-Berlin Axis and the Destruction of Collective Security, and to my wife, who has encouraged me throughout. 